\title{
Recombinant Fibroblast Growth Factor 1
}

National Cancer Institute

\section{Source}

National Cancer Institute. Recombinant Fibroblast Growth Factor 1. NCI Thesaurus. Code C1750.

A recombinant therapeutic agent which is chemically identical to or similar to endogenous fibroblast growth factor 1 (FGF-1. Because of the mitogenic and angiogenetic effects of FGF-1 on fibroblasts and endothelial cells, therapeutic FGF-1 has a potential role in wound healing; because FGF-1 has been shown to induce neurogenesis, therapeutic FGF-1 may have a role in nerve regeneration. $(\mathrm{NCIO4})$ 